\title{
A FULL SPECTRUM OF LIGHT: RETHINKING THE CHARITABLE CONTRIBUTION DEDUCTION
}

\author{
ToDD Izzo†
}

\begin{abstract}
A philosophereconomist might observe that the opportunity cost of virtue falls as one moves up the income scale. ${ }^{1}$
\end{abstract}

\section{INTRODUCTION}

In 1992, the federal government provided a $\$ 17$ billion subsidy to the nation's charitable organizations ${ }^{2}$ by allowing individuals ${ }^{3}$ a deduction ${ }^{4}$ for contributions to qualified charitable organizations $^{5}$ in the calculation of taxable income. The funding of

† B.S. 1991, Pennsylvania State University; C.P.A. Candidate 1994; J.D. Candidate 1994, University of Pennsylvania. I would like to thank Professor Reed Shuldiner for his insightful comments and suggestions. In addition, I am indebted to the work of my fellow Law Review editors, especially Joel Mick and Bruce Greenblatt for their comments on earlier drafts, and Margaret Scott for her support. In particular, I would like to thank my parents, especially my father for his insight and valuable suggestions.

I Richard A. Musgrave \& Peggy B. Musgrave, Public Finance in Theory and PrACTICE 362 (3d ed. 1980).

${ }^{2}$ See Staff of Joint Comm. On Taxation, 102d Cong., 2D Sess., Estimates of Federal TAX EXPENDITURes for FisCAL YeARS 1993-97, at 21 (Comm. Print 1992) [hereinafter ESTIMATES]. The amount for 1993 is estimated at $\$ 17.8$ billion. See id. at $15-16$.

${ }^{3}$ Although corporations are permitted a similar deduction, this Comment will discuss only the deduction for individuals. See I.R.C. \$170 (1988 \& Supp. III 1991) (stating that corporations may make deductions for charitable contributions). The total amount of the tax expenditure for the charitable contributions of corporations is quite small in comparison to that for individuals. See ESTIMATES, supra note 2, at 15-16 (estimating that corporate donations will account for only $8 \%$, or $\$ 1.5$ billion, of the total $\$ 19.3$ billion tax expenditure for charitable contribution deductions in 1993). It also does not appear that the issues presented in this Comment arise in the context of corporate charitable contributions.

${ }^{4}$ See I.R.C. $\$ 170(\mathrm{a})(1)$ ("There shall be allowed as a deduction any charitable contribution ...."). A deduction is a reduction in "gross income in arriving at net income for tax purposes." BLACK'S LAW DICTIONARY 413 (6th ed. 1990).

${ }^{5}$ Charitable organizations must satisfy the requirements of $\S 501(c)(3)$ of the Internal Revenue Code. See I.R.C. $\$ 501(c)(3)$ (1988). Such organizations must be "organized and operated exclusively for religious, charitable, scientific, testing for public safety, literary, or educational purposes, or to foster ... amateur sports competition . . . or for the prevention of cruelty to children or animals . . . and [must] not participate in, or intervene in ... any political campaign .... Id. The IRS publishes a two-volume list of all organizations that qualify for the deduction. See INTERNAL REVENUE SERV., CUMULATIVE LIST OF ORGaNIZATIONS (1992). Over 200,000 organizations are listed ranging from the AAA Scholarship Fund of the Lehigh Valley 
charitable organizations through the allowance of a deduction is an example of a tax expenditure. ${ }^{6}$ Permitting a deduction against taxable income operates as a subsidy to charitable organizations by reducing the taxes of individuals who contribute to those organizations.

For example, if a taxpayer at the $15 \%$ marginal tax rate $^{7}$ is entitled to deduct the $\$ 100$ that she donated to a qualified charity, then the deduction reduces her taxable income by $\$ 100$ and her tax liability by $\$ 15,{ }^{8}$ lowering the net opportunity cost of her charitable contribution to $\$ 85$. Assuming the taxpayer was prepared originally to make a donation of $\$ 100$ without a tax subsidy, the presence of the tax subsidy will induce her to increase her donation to $\$ 118$, because a donation of that amount will reduce her tax liability by $\$ 18,{ }^{9}$ returning the net cost of her donation to $\$ 100 .^{10}$ Empirical research bears out the assumption that the existence of a deduction will induce taxpayers, on average, to increase their contributions

Motor Club to the Zuni Canyon Institute and representing viewpoints as potentially adverse as the Right to Life Education Committee and the Pro-Choice Education Society. See 1 id. at $1 ; 2$ id. at 449, 502, 956.

6 “'Tax Expenditures' are defined . . . as reductions in individual and corporate income tax liabilities that result from special tax provisions ... . These special tax provisions can take the form of exclusions, credits, deductions, preferential tax rates, or deferrals of tax liability." ESTIMATES, supra note 2, at 2. Whatever their form, tax expenditures "are considered to be analogous to direct outlay programs, and the two can be viewed as alternative means of accomplishing similar budget policy objectives .... They are a measure of the economic benefits that are provided through the tax laws to various ... sectors of the economy." Id. Reducing tax revenue by allowing a deduction from taxable income is an alternative to collecting the money in tax revenue and then spending it on the sector of the economy benefitted by the deduction. In the case of charitable contribution deductions, charitable organizations are the benefactors.

${ }^{7}$ A taxpayer's marginal tax rate is the "tax rate on the last dollar of taxable income." BLACK'S LAW DICTIONARY 1462. For example, if a taxpayer faces a marginal tax rate of $20 \%$, her next dollar of income increases her taxes by 20 cents. Contrast a taxpayer's average rate-the percentage of tax paid with respect to income as a whole. For instance, if a taxpayer has income of $\$ 20,000$ and pays taxes of $\$ 4,000$, her average rate is $20 \%(\$ 4,000$ divided by $\$ 20,000$ equals $20 \%)$.

${ }^{8}$ The following example is illustrative. If the taxpayer has taxable income of $\$ 20,000$ and faces a marginal (and average) tax rate of $15 \%$, her resulting total tax liability is $\$ 3000$ ( $\$ 20,000$ multiplied by $15 \%$ equals $\$ 3000)$. If she donates $\$ 100$ to charity and is entitled to a deduction, her taxable income reduces to $\$ 19,900$ and her corresponding tax liability to $\$ 2985$ ( $\$ 19,900$ multiplied by $15 \%$ equals $\$ 2985)$. The $\$ 15$ decrease in her tax liability from $\$ 3000$ to $\$ 2985$ is equal to the amount of the deduction, $\$ 100$, times the marginal tax rate of $15 \%$.

9 The $\$ 118$ deductible donation multiplied by her $15 \%$ tax rate is approximately equivalent to an $\$ 18$ tax savings.

${ }^{10}$ The $\$ 100$ net cost of her donation is computed by subtracting the $\$ 18$ tax savings from her $\$ 118$ donation. 
rather than simply pocketing the tax savings. ${ }^{11}$ Thus, the federal government has in effect donated money to the charitable organization through its allowance of a deduction, inducing an increase in the charitable organization's receipts from $\$ 100$ to $\$ 118$.

Perhaps more importantly is the mechanism by which this subsidy to charitable organizations is provided. Generally, Congress allocates government money among competing interests; here, the individual taxpayer chooses how to allocate public money ( $\$ 18$ in the preceding example) by deciding which charitable organization she wishes to support. This power, however, is not extended to all taxpayers. Under the current Internal Revenue Code (the "Code"), only taxpayers who itemize deductions are entitled to deduct charitable contributions from their taxable income. ${ }^{12}$ Since highincome taxpayers are most likely to be itemizers, ${ }^{13}$ they have the greatest voice in selecting which charitable organizations receive government subsidies through the current tax deduction mechanism. In addition, charitable organizations receiving donations from high-income taxpayers enjoy a larger subsidy than that provided by low-income taxpayers because the marginal tax rate for high-income taxpayers is higher under our current progressive rate structure. ${ }^{14}$

${ }^{11}$ See infra part II.C.3. In fact, this research indicates that the effect of the tax subsidy on such a taxpayer would actually induce her to increase her donation by more than $\$ 18$, even though this would increase her net cost above the $\$ 100$ she was originally willing to give. See infra part II.C.3. Thus, contributions to charity are increased by an amount greater than the decrease in taxes resulting from the deduction. See infra part II.C.3; see also Martin Feldstein, A Contribution to the Theory of Tax Expenditures: The Case of Charitable Giving in THE ECONOMICS OF TAXATION 99, 104-06 (Henry J. Aaron \& Michael J. Boskin eds., 1980).

12 This fact can be gleaned from the Code by virtue of I.R.C. $\$ 63(\mathrm{~b})$. Section 63(b) defines the taxable income of an individual who does not itemize deductions as adjusted gross income ("AGI") less the standard deduction and the personal exemption of I.R.C. $\S 151$. See I.R.C. \$§ 63(b), 151 (1988 \& Supp. III 1991). AGI "represents gross income less business expenses, expenses attributable to the production of rent or royalty income, the allowed capital loss deduction and certain personal expenses." BLACK's LAW DICTIONARY 43; see also I.R.C. § 62 (1988 \& Supp. III 1991). A standard deduction is "a minimum amount allowed to individual taxpayers as a deduction from [AGI] in arriving at taxable income" and a personal exemption is "an amount allowed as a deduction from [AGI] in arriving at taxable income." BLACK's LAW DICTIONARY 572, 1404; see also I.R.C. $\$ \$ 63,151$. By defining taxable income in this manner, the Code implicitly does not permit nonitemizers a deduction for charitable contributions.

${ }^{13}$ In 1988, for example, the median income of nonitemizers was $\$ 11,632$, while the median income of itemizers was \$42,913. See INTERNAL REVENUE SERV., INDIVIDUAL INCOME TAX RETURNS 1988, at 34 (1989). Of the roughly 78 million taxpayers who did not itemize, $80 \%$ had AGI below $\$ 25,000$. See id. at $2,21$.

${ }^{14}$ A progressive tax structure imposes a higher marginal tax rate as a taxpayer's 
Under the present system a low-income taxpayer who does not itemize deductions and contributes $\$ 100$ to a qualified charity will bear the full cost of her donation, since she will pay the same total federal income tax whether or not she contributes the $\$ 100$. In contrast, a high-income taxpayer who itemizes deductions and faces the highest marginal tax rate of $31 \%$ is entitled to deduct the $\$ 100$ contribution in calculating her taxable income, decreasing her tax liability by $\$ 31$. The government subsidizes $31 \%$ of the high-income taxpayer's contribution but none of the low-income taxpayer's contribution. This effect magnifies the disparity between the government's subsidy of the two taxpayers' chosen charities. The higher-income taxpayer is now willing to donate more than $\$ 100$ because the contribution "costs less," thereby giving the charitable organization an even greater subsidy. Meanwhile, the low-income taxpayer's chosen charity receives no subsidy for her contribution.

As this example illustrates, the current system is really an inequitable "upside-down subsidy." 15 The ultimate result of channeling government funds to charitable organizations through the mechanism of an itemized deduction is that predominantly highincome taxpayers decide which charitable organizations are entitled to the $\$ 17$ billion of federal money expended. ${ }^{16}$ Low-income taxpayers are denied a voice in this decision. The present tax system provides no subsidy to the charities of the more than twentytwo million households that do not earn enough to file a tax return, ${ }^{17}$ nor does it subsidize the contributions of the seventyeight million households ( $71 \%$ of all federal taxpayers) who file returns but do not itemize deductions. ${ }^{18}$ Furthermore, the current

income increases. See Michael J. Graetz, Federal Income TAXation 12 (2d ed. 1988). In 1992, a single taxpayer paid a $15 \%$ tax on her first $\$ 21,450$ of taxable income, $28 \%$ on the next $\$ 30,450$, and $31 \%$ on taxable income in excess of $\$ 51,900$. See I.R.C. § 1(c), (f) (1988 \& Supp. III 1991).

${ }^{15}$ See The Donee Group, Private Philanthropy: VITAL aNd INNOVATIVE OR PASSIVE AND IRRELEVANT 72 (1977) (describing the upside-down subsidy as the "great inequity of the present system"); Stanley S. Surrey, Tax Incentives as a Device for Implementing Government Policy: A Comparison with Direct Government Expenditures, 83 HARV. L. REV. 705, 720-25 (1970) (stating that tax incentives are inequitable because they are worth more to the high-income taxpayer than to the low-income taxpayer).

${ }^{16}$ See supra text accompanying notes 2-5.

17 See U.S. DeP'T OF Commerce, Statistical AbSTRact of The United States 452 (1991) [hereinafter STATISTICAL ABSTRACT] (noting that there were approximately 91 million households in the nation, of which $68,770,000$ paid federal income taxes).

${ }^{18}$ See INTERNAL REVENUE SERV., supra note 13, at 2 (stating that 110 million 
disparity will grow worse in the coming years. The Omnibus Budget Reconciliation Act of $1993^{19}$ has increased the progressivity of the income tax by raising the marginal tax rate imposed on the nation's highest-income taxpayers, ${ }^{20}$ thereby also increasing the already disproportionate subsidizing of charities favored by such taxpayers.

In order to solve this existing and potentially increasing inequity, this Comment proposes that the current itemized deduction for charitable contributions be replaced by a refundable tax credit $^{21}$ available to all Americans, that is, itemizers, nonitemizers, and nonfilers alike. Returning to our example, if an upperand lower-income taxpayer each donate $\$ 100$, they both will receive a $\$ 20$ reduction in their tax liability, despite the difference in their marginal tax rates. Moreover, the refundability of the tax credit permits the person with no tax liability to provide a government subsidy to the charity of her choice by making a donation. ${ }^{22} \mathrm{~A}$ credit thus democratizes the choice of how the government allocates the $\$ 17$ billion of federal subsidies to charity. ${ }^{23}$

taxpayers filed returns but only 32 million itemized deductions in 1988).

${ }_{19}$ Pub. L. No. 103-66 (Aug. 10, 1993) (to be codified at scattered sections of 26 U.S.C.).

${ }^{20}$ See id. $\S \S 13201,13202$ (raising the highest marginal tax rate to $36 \%$ for single taxpayers with taxable income exceeding $\$ 115,000$ ( $\$ 140,000$ for married taxpayers filing joint returns) and establishing a "high income" surtax on individuals with taxable income in excess of $\$ 250,000$, raising the effective marginal rate for such taxpayers to $39.6 \%$ ).

21 For the sake of example, this Comment will assume a $20 \%$ credit. The $20 \%$ figure is a rough estimate of the level of credit needed to maintain the current revenue cost and total level of charitable giving. See infra note 127.

22 A deduction has no value to an individual with no tax liability. A refundable credit, by contrast, entitles an individual to receive a cash payment from the Treasury in the amount that the credit exceeds his tax liability. The current earned income tax credit to low-income individuals who maintain households for their minor children is an example of a refundable tax credit. See I.R.C. $\$ 32$ (Supp. III 1991).

${ }^{23}$ Some critics may argue that even an equal credit provided for the donations of both low- and high-income taxpayers will still result in the government disproportionately subsidizing the philanthropic decisions of high-income taxpayers, because the total amount of an individual's contributions and the corresponding subsidy to the charitable organization will increase with income. See Peter J. Wiedenbeck, Charitable Contributions: A Policy Perspective, 50 Mo. L. REv. 85, 96 n.41 (1985) (citing studies which indicate a positive income elasticity for charitable giving). For example, under a credit system of $20 \%$ if an individual earning $\$ 100,000$ donates $\$ 1000$, and an individual earning $\$ 10,000$ donates $\$ 100$, the higher-income taxpayer will designate a subsidy of $\$ 200,10$ times that of the lower-income taxpayer's $\$ 20$, though they both receive an equal $20 \%$ subsidy in percentage terms. The fact that the amount of an individual's donation increases with income exacerbates the inequity of the current 
If we accept former President Bush's oft-quoted analogy that the private philanthropy of our nation's individuals is akin to "a thousand points of light, ${ }^{24}$ current government policy can be viewed as disproportionately supporting the points of light of our nation's wealthiest. If the philanthropic light of individuals across income levels is viewed as a spectrum, the current system fails to provide support for the light provided by the low-income portion of the spectrum. A change to a refundable tax credit will grant equal support for the philanthropic light of all Americans regardless of income, and encourage an entire spectrum of charitable giving.

Part I of this Comment presents an overview of the historical development of the tax treatment of charitable contributions. Part II examines the alternative theoretical and policy rationales underlying the income tax treatment of contributions by individuals to charitable organizations. Part III provides an example of the current system and critiques its plutocratic nature. In Part IV, this Comment proceeds to examine alternatives to the current system, considering a system of direct matching grants, a deduction for nonitemizers as set forth in a bill currently before Congress, ${ }^{25}$ and finally, the most desirable alternative, proposing a revenue-neutral change to a refundable tax credit.

system. This problem could be resolved by decreasing the credit as income rises. In our preceding example, the inequity could be eliminated by entitling the lowerincome taxpayer to a credit of $20 \%$ and the higher-income taxpayer a credit of $2 \%$.

This Comment chooses not to advocate a credit that decreases as income rises. Arguably, a large part of the inequity of the current system arises from a framework that treats the individual contribution decisions of taxpayers differently depending on one's income. The current system does not provide equal treatment for all individuals under the law. A flat credit would equally subsidize the individual philanthropic decision of each taxpayer irrespective of income.

24 See The Inauguration of George Bush, L.A. TIMES, Jan. 21, 1989, at 20.

${ }^{25}$ See H.R. 152, 103d Cong., 1st Sess. (1993) (stating its purpose as "to restore and make permanent" I.R.C. $\$ 170(i)$ allowing a "deduction for charitable contributions by nonitemizers"). The presence of this bill is a hopeful sign of reform since congressional attention has been drawn to the issue. Senator Moynihan's rise to chairman of the Senate Finance Committee also increases the possibility of a reform of the tax funding of charitable organizations. See Rick Wartzman, Charities Cheer, WALL ST.J., Dec. 16, 1992, at A1 (describing Moynihan as the "best friend charity has ever seen" and as an individual who "once championed letting nonitemizers make charitable deductions"). 


\section{A Brief History of the InCOME TAX TREATMENT OF INDIVIDUAL CONTRIBUTIONS TO CHARTTABLE ORGANIZATIONS}

The tax preference granted individual contributions to charitable organizations has a long history in the federal income tax law. ${ }^{26}$ The introduction of the standard deduction in $1944^{27}$ and its expansion in 1986, however, effectively eliminated the subsidy to charitable organizations for a majority of taxpayers, removing the opportunity for many middle- and low-income taxpayers to deduct their contributions. ${ }^{28}$ The adverse effect of the standard deduc-

${ }^{26}$ Individuals were first permitted a deduction for charitable contributions in 1917 , four years after the enactment of the individual income tax. See CHARLES T. Clotfelter, FEderal TAX POLICY AND CHARTTABLE GIVING 11 (1985); see also War Revenue Act of 1917, ch. 63, § 1201(2), 40 Stat. 300, 330 (1919). The income tax of 1917 , which was levied almost exclusively on the wealthiest citizens, created concern regarding the availability of income for philanthropy. See CLOTFELTER, supra, at 31. Senator Hollis, the sponsor of the amendment which created the deduction for contributions, stated in the Congressional Record of 1917: "[if] we impose these very heavy taxes on incomes . . . that will be the first place where these very wealthy men will be tempted to economize, namely, in donations to charity." Id. The majority of subsequent refinements to the law took place in 1969. See Tax Reform Act of 1969, Pub. L. No. 91-172, $\S \S 101,121,201,83$ Stat. 487, 492-565, 1969 U.S.C.C.A.N. 509, 513, 568, 584 (codified as amended at I.R.C. $\$ \S 170,501-526$ (1988 \& Supp. III 1991)).

${ }^{27}$ Added during World War II, a time of increased income tax coverage of the citizenry, the standard deduction was advocated as a means of simplifying compliance for the multitude of lower-income taxpayers added to the tax rolls. See ClOTFELTER, supra note 26, at 25, 32 (explaining that the standard deduction was added in hope that it would "achieve high compliance with a minimum of administration").

${ }^{28}$ Whether or not the inability of low- and middle-income taxpayers to deduct charitable contributions should be viewed as inequitable depends upon the rationale behind the standard deduction. If the rationale behind the charitable contribution deduction is not income measurement, see infra part II.A., then the standard deduction could be viewed as a substitute for only those expenses which are deductible because the government wishes to accurately measure taxable income, and not for those which are deductible because the government wishes to encourage a particular activity, such as charitable giving. See infra part II.B.

In addition, if the standard deduction is considered a substitute for a taxpayer's itemized deduction, then the disallowance of a deduction to nonitemizers is justified on the grounds that their deduction for charitable contributions is included within the standard deduction. If, however, the purpose of the standard deduction is to remove lower-income taxpayers from the tax rolls, as was a "heralded" consequence of the 1986 Act, then the disallowance of a tax preference for nonitemizers cannot be justified. See GraETZ, supra note 14, at 508. For instance, in 1992 the standard deduction was $\$ 3600$ for a single person. If a taxpayer had $\$ 300$ of charitable contribution deductions, and $\$ 1000$ of other qualified itemized deductions, the standard deduction would provide a $\$ 2300$ benefit in the form of an additional deduction if viewed as a substitute for an insufficient amount of itemized deductions. 
tion on charitable giving did not go unnoticed.

The proposal brought on a storm of opposition on the basis that the incentive effect of the charitable deduction would be lost. Representative Carl Curtis stated, "[t]his bill, when carried into effect, means that the individual who gives a portion of his hardearned money in contributions will have the same amount of taxes withheld from his wages as if he had given nothing. ${ }^{29}$

Nevertheless, the desire for simplification triumphed over concerns regarding the demise of the incentive effect. ${ }^{30}$ Also in the name of simplification, the Tax Reform Act of $1986^{31}$ ("1986 Act") further decreased the number of itemizers, and thus, the number of taxpayers capable of indirectly creating subsidies for charities by taking the charitable contribution deduction. ${ }^{32}$

Even before the 1986 Act, to counteract the erosion of the subsidy, the Economic Recovery Tax Act of $1981^{33}$ included a provision which phased in a deduction for nonitemizers. ${ }^{34}$ Although this provision expired in $1986,{ }^{35}$ there is currently a bill before Congress which proposes to re-establish such a deduction. ${ }^{36}$

If the standard deduction of $\$ 3600$ is viewed, when combined with the personal exemption of $\$ 2300$, as a mechanism to eliminate individual taxpayers with less than $\$ 5900$ of income from the tax rolls, then the disproportionate treatment of nonitemizers' contributions is not justified.

${ }^{29}$ Clotfelter, supra note 26 , at 32.

${ }^{30}$ See id.

31 Pub. L. No. 99-514, 1986 U.S.C.C.A.N. (100 Stat.) 2085 (codified as amended in scattered sections of 26 U.S.C.).

32 See INTERNAL REVENUE SERV., supra note 13, at 2 (stating that the number of taxpayers who itemized deductions decreased by $20 \%$ from 1985 to 1988); GRAETZ, supra note 14, at 508 (noting that the 1986 Act was designed to decrease the number of itemizers through the increase in the amount of the standard deduction, the disallowance of consumer interest deductions, and the imposition of a $2 \%$ adjusted gross income floor on miscellaneous deductions).

${ }^{33}$ Pub. L. No. 97-34, 1981 U.S.C.C.A.N. (95 Stat.) 172 (codified as amended in scattered sections of 26 U.S.C.).

${ }^{34}$ Section 121(a) of the Economic Recovery Tax Act of 1981 modifies I.R.C. $\$ 170$ by granting nonitemizers a deduction of $25 \%$ of the first $\$ 100$ of donations in 1982 and $1983,25 \%$ of the first $\$ 300$ in $1984,50 \%$ without limit in 1986 , and full deductibility in 1986. See id. (\$ 121(a) codified at I.R.C. $\$ 170$ (1988 \& Supp. III 1991)).

${ }^{35}$ The provision was set to expire on December 31,1986 , and was not renewed. It was officially repealed in 1990. See Omnibus Budget Reconciliation Act of 1990, Pub. L. No. 101-508, § 11801(a)(11), 1990 U.S.C.C.A.N. (104 Stat.) 1388, 1388-520. ${ }^{36}$ See infra part IV.B. 


\section{The Alternative Rationales Behind the Tax Treatment of ChartTABle CoNTRIBUTIONS}

\section{A. Andrews's Income Measurement Approach}

The deduction for contributions to charitable organizations is predicated on two alternative rationales. One justification is that it is necessary to accurately measure an individual's income, since the portion donated to charity is not available for personal consumption or savings. ${ }^{37}$ Defining income as the amount of a person's consumption plus the change in her wealth, ${ }^{38}$ Andrews asserts that gifts to charity should not be considered consumption. He argues that if the income tax is viewed as a mechanism to "divert economic resources away from personal consumption and accumulation" to public use, ${ }^{39}$ then only the consumption of resources which divert "economic resources away from other people [should be considered consumption] in assessing income taxes. ${ }^{n 0}$ Since charitable donations do not divert resources to private use, but rather to public use (to the extent that charitable organizations provide public goods), ${ }^{41}$ Andrews argues that donations should not be viewed as

37 See William D. Andrews, Personal Deductions in an Ideal Income Tax, 86 HARV. L. REV. 309, 312 (1972).

${ }^{38}$ This widely-accepted definition of income is attributed to Robert Haig and Henry Simons. See Henry C. Simons, Personal Income Taxation 50 (1938) ("Personal income may be defined as the algebraic sum of (1) the market value of rights exercised in consumption and (2) the change in the value of the store of property rights between the beginning and end of the period in question."); Robert M. Haig, The Concept of Income-Economic and Legal Aspects, in THE FEDERAL INCOME TAX 7 (Robert M. Haig ed., 1921) ("Income is the money value of the net accretion to one's economic power between two points of time.").

${ }^{39}$ Andrews, supra note 37, at 325.

40 Id. at 356.

41 Public goods are those commodities or services that, when purchased, provide benefits to nonpurchasers. Such goods are characterized by "nonrival consumption" (consumption by one person does not reduce the benefit available to others) and "nonexclusion" (an inability to practically exclude the external benefits). See ROY J. RUFFin \& PAUL R. GREGORY, PRINCIPLES OF MiCROECONOMICS 452-53 (3d ed. 1988).

The unique nature of public goods creates the "free-rider problem," which causes the market to undersupply such goods. "A free rider is anyone who enjoys the benefits of a good or service without paying the cost." Id. at 454 . The market is unwilling to supply goods on which individuals can "free ride." The government, on the other hand, is able to provide such goods because it can compel payment for their costs by employing its taxing power.

Education, for instance, is often thought of as a good that results in benefits to nonpurchasers. Because the benefit of an educated populace can be enjoyed even by those who do not pay the costs of education, society's demand for education is not fully reflected in its market price. Only through government intervention is the full 
consumption, and thus charitable donations are properly deducted in the Haig-Simons calculation of taxable income. ${ }^{42}$

\section{B. The Deduction as a Tax Subsidy}

An alternative and, this Comment will argue, superior view of the tax preference for charitable donations is that the favorable treatment of individual donations exists to provide a subsidy to charitable organizations because these organizations furnish public goods. The tax subsidy is an alternative to direct government provision of such goods.

Andrews's view that a deduction is necessary for the accurate measurement of taxable income has been appropriately criticized as merely "repackag[ing] the arguments for subsidizing charities," 43 or "flip[ping] the argument for subsidizing charities on its head." ${ }^{44}$ Andrews presupposes that charitable organizations are deserving of public support, since they provide public goods. He then incorpo-

demand for education reflected in the price and the proper amount of education provided. Similarly, it has been argued that the government should subsidize the war on poverty, because a reduction in the higher crime rate and animosity associated with divergent wealth allocation is a public good unlikely to be adequately provided by the private market. See RICHARD A. POSNER, ECONOMIC ANALYSIS OF LAW 465 (4th ed. 1992) (arguing that "there are free-rider problems" that support "an argument for forcing people to contribute to the alleviation of poverty so that they cannot take a free ride on private donations to charity").

Services provided by charitable organizations are in the nature of public goods. See Wiedenbeck, supra note 23 , at 94 . Wiedenbeck gives the examples of the services provided by hospitals, museums, and colleges. He argues that there would be inadequate consumption of such services if they were available only to those who could afford to pay a price reflecting the full price. See id. Thus, government support is "based on a social policy decision that such cultural and educational opportunities should be available" to more people than "free market pricing would permit." Id. Charities which provide services to the poor are also providing a public good. See RUFFIN \& GRECORY, supra, at 457 (arguing that "[ $\mathrm{t}$ ] he welfare of those with strong altruistic feelings towards the poor will be improved by a redistribution of income in favor of the poor" and that private insurance cannot solve the problem of poverty since the market does not provide "soverty' insurance, even though random events such as bad health, technological progress, accidents, and changes in taste can cause poverty"). For example, the Salvation Army provides food and shelter to the downtrodden, providing a social good by, among other things, alleviating some of the costs poverty imposes on society.

42 See Andrews, supra note 37, at 356.

${ }^{43}$ Mark P. Gergen, The Case for a Charitable Contributions Deduction, 74 VA. L. REV. 1393, 1416 (1988).

${ }^{44} I d$. at 1421. 
rates this presumption into his definition of income, excluding from income those expenses he deems worthy of a subsidy. ${ }^{45}$

The alternative view simply makes explicit what is implicit in Andrews's view. Charitable giving is viewed as an item of "discretionary spending that warrants an incentive. ${ }^{\$ 46}$ The tax deduction for charitable contributions merely encourages people to "do voluntarily what we would otherwise have to coerce them to do (i.e., fund collective goods). ${ }^{n 7}$ This conception of the deduction as a subsidy of charitable giving is consistent with the view among some economists that charity is a form of personal consumption. ${ }^{48}$ If charitable giving is considered as a form of personal consumption, then it is properly included in income, ${ }^{49}$ with a deduction viewed as providing a subsidy for this preferable form of consumption.

The importance of this distinction is as follows: if the deduction is necessary for the proper measurement of income, as Andrews suggests, then a credit or any other alternative subsidy mechanism is inappropriate because the lack of a deduction overstates taxable income. If, on the other hand, the deduction exists simply to subsidize charitable organizations and not to measure income, then the "form of [the] tax subsidy is not determined a priori, but rather is a question subject to normative policy analysis. ${ }^{" 50}$ Thus, because the deduction is properly conceptualized as a tax subsidy, we are free to consider policy considerations when deciding which mechanism should be used to provide the subsidy.

\section{Direct Budget Outlays or Indirect Subsidy?}

If the current deduction for charitable donations is seen as a means of subsidizing the provision of public goods by charitable organizations, is it preferable for government to support the provision of such goods through direct budget outlays to particular

${ }^{45}$ See id.

46 See Clotfelter, supra note 26, at 280.

47 Gergen, supra note 43 , at 1421 .

48 CLOTFELTER, supra note 26 , at $280 \mathrm{n} .3$ (recognizing that the view of charity as a form of consumption is "conformable to the proclivities of many economists" (quoting Richard E. Wagner, Death, Taxes, and Charitable Bequests: A Survey of Issues and Options, in 4 RESEARCH PAPERS 2337, 2342 (Commission on Private Philanthropy and Pub. Needs, U.S. Dep't of the Treasury ed., 1977))); see also infra notes 94-98 and accompanying text.

${ }^{49}$ For the Haig-Simons definition of income, which includes consumption within the definition, see supra note 38 and accompanying text.

${ }^{50}$ Clotfelter, supta note 26, at 280. 
charitable organizations or via a subsidy of the charitable giving of individuals through the current tax expenditure mechanism? The following considerations indicate that indirect support of the charitable contributions of individuals is more desirable than direct government support of charitable organizations.

\section{Cultural Pluralism}

The first argument in support of a tax subsidy approach is that it encourages, unlike direct government expenditure, cultural pluralism. ${ }^{51}$ The recipients of direct government expenditures are chosen through a majoritarian process, "which may lead to a tyranny of the majority. For example, if the voting population likes public TV but doesn't like fine art or music, government-only support through the tax and appropriation process would result in a uniform, perhaps stifling, set of cultural and educational opportunities." 52 In contrast, support of art, music, religion, education, and other social services via a tax subsidy allocates budgetary priorities through a system which funds the individual choices of the populace. "The deduction encourages pluralism by permitting an assortment of social services; taxpayers are allowed in part to vote with their dollars, rather than by the one-person, one-vote system that establishes ... . budget priorities. ${ }^{\text {53 }}$

Many of the "meritorious social programs" currently provided for by the tax expenditure for charitable giving "as a political matter, could not be transplanted from the tax to the spending side of the federal budget." ${ }^{54}$ The recent controversy over the direct public funding of controversial artistic works through the National Endowment for the Arts is a prime example of the problems caused by majoritarian control of public funding for charitable endeavors. ${ }^{55}$ Under an indirect system of support, those individuals who want to fund charitable organizations that support controversial artistic works have the ability to allocate federal funds for that purpose through an indirect tax expenditure, ensuring a rich

${ }^{51}$ See Wiedenbeck, supra note 23, at 97 ("[T] he charitable contribution deduction fosters the coexistence of nonmajoritarian values-it encourages experimentation by the private sector in new solutions to our social problems. ${ }^{\text {) }}$.

52 Id. at 96.

53 Id. at 97 (footnote omitted).

${ }^{54}$ Id. at $96 \mathrm{n} .42$ (emphasis omitted).

${ }^{55}$ See Patti Hartigan, Senate Rejects Helms' New NEA Restrictions, BOSTON GLOBE, Nov. 1, 1991, at 25 (describing the "arduous two-month debate in Congress over [direct budgetary] allocations for the National Endowment for the Arts"). 
diversity of cultural endeavors not possible when funding decisions must be made by majoritarian choice. As Posner argues, the support of charities through a tax expenditure is "politically important because it transfers from the government to the individual taxpayer some of the power to decide who shall be recipients of altruistic transfers, a decision that in most societies is made at the political level. ${ }^{n 6}$ Support of charitable organizations through a system of indirect support allows the donor to exercise "a form of self-government ... that parallels, complements and enriches the democratic electoral process itself" by "saying with his or her dollars what needs should be met, what objectives pursued, what values served. ${ }^{n 57}$

\section{Constitutionality}

The second argument in favor of an indirect subsidy is that it allows for the support of religiously affiliated charitable institutions for which direct government support is unconstitutional. ${ }^{58}$ The Supreme Court held in Walz v. Tax Commission ${ }^{59}$ that a subsidy provided to religious organizations through a tax expenditure does

${ }^{56}$ POSNER, supra note 41 , at 496 . The problem with the current system, however, is that this power is vested only in those high-income taxpayers who itemize. See supra notes 12-20 and accompanying text; infra part III.B.

57 Commission on PrIVATE PhILANTHROPy \& Pub. NEEds, Giving In AMERICA 123 (1975) [hereinafter GIVING IN AMERICA]. This system of budgetary allocation ensures government support of charitable endeavors while alleviating libertarian concern over the liberty infringements inherent in majoritarian social planning. See generally FRIEDRICH A. HAYEK, THE ROAD TO SERFDOM (1944) (warning against such infringements). A broad array of social services could in theory be provided by charitable organizations supported by this pluralistic funding mechanism without the loss of individual freedom associated with majoritarian government control. Critics, however, lament this lack of majoritarian control. See MUSGRAVE \& MUSGRAVE, supra note 1 , at 362 (" $[I] t$ is argued that some of the functions now supported by charity should be the responsibility of the state and that allocations made from public funds ... should be subject to public discretion and scrutiny.").

${ }^{58}$ Direct government support of religious organizations is constitutionally prohibited by the Establishment Clause. See U.S. CoNST. amend. I "Congress shall make no law respecting an establishment of religion. . . ."); Walz v. Tax Comm'n, 397 U.S. 664,675 (1970) (suggesting that a direct money subsidy to religious organizations "would be a relationship pregnant with involvement" that would violate the Establishment Clause).

The importance of the constitutionality of the deduction for religious contributions might be heightened under a tax credit system. A credit would increase the subsidy produced by low-income taxpayers, who disproportionately support religious organizations. See infra part III.B.

39397 U.S. 664 (1970) (considering the constitutionality of the property tax exemption granted to churches). 
not violate the Establishment Clause because it does not involve excessive government entanglement with religion. ${ }^{60}$ This is the correct result if the harm in government support of religion embodied in the Establishment Clause is the coercive effect of government involvement in matters regarding individual religious freedom. Unlike direct budget outlays, a system of subsidizing individual philanthropic choices does not create concerns of government coercion because a tax subsidy involves little or no government control over the subsidy. In Corporation of the Presiding Bishop v. Amos, ${ }^{61}$ the Court stated that the Establishment Clause "does not mean that the law's purpose must be unrelated to religion ... and the Establishment Clause has never been so interpreted."62 Rather, the clause "aims at preventing the relevant governmental decisionmaker ... from abandoning neutrality and acting with the intent of promoting a particular point of view in religious matters." 43 A subsidy that is allocated based on the individual decisions of each citizen clearly does not involve government advocacy of a particular religious point of view and should thus satisfy the Amos test. ${ }^{64}$

In addition, perhaps government should go further than merely refraining from improperly favoring one religion over another and

${ }^{60}$ See id. at 675 ("[T]he questions are whether [government] involvement is excessive, and whether it is a continuing one calling for official and continuing surveillance leading to an impermissible degree of entanglement."). The decision in Walz has been generally viewed as supporting the constitutionality of a deduction for contributions to charitable organizations. See, e.g., Wiedenbeck, supra note 23, at 95 \& $\mathrm{n} .40$ (citing Walz as support for his statement that "benefit to an individual donortaxpayer through the general charitable contribution deduction does not violate the establishment clause $\left.{ }^{n}\right)$.

61483 U.S. 327 (1987).

62 Id. at 335 .

63 Id.

${ }^{64}$ It does appear possible, however, for the IRS to violate the Establishment Clause when it decides which charitable contributions are deductible. In Hernandez v. Commissioner, 490 U.S. 680 (1989), Justices O'Connor and Scalia argued in dissent that the disallowance of a deduction by the IRS for payments made to the Church of Scientology for auditing and training services constituted a violation of the Establishment Clause. Id. at 713 (O'Connor, J., dissenting).

[T] ] IRS has misapplied its longstanding practice of allowing charitable contributions under section 170 in a way that violates the Establishment Clause. It has unconstitutionally refused to allow payments for the religious service of auditing to be deducted as charitable contributions in the same way it has allowed fixed payments to other religions to be deducted.

Id. Efforts to relitigate the Hernandez holding are under way. See Powell v. United States, 945 F.2d 374 (11th Cir. 1991) (remanding to the district court). 
view "religious tolerance [not as] a negative principle [but as] a positive commitment that encourages the flourishing of conscience" ... and to "consider whether a nation committed to religious pluralism must, in the age of the affirmative state, make active provision for maximum diversity. ${ }^{n 65}$ The charitable contribution deduction is such a provision, encouraging religious pluralism by subsidizing the myriad of individual decisions to contribute to diverse qualified religious organizations.

Finally, in addition to the value of diversity in its own right, it can be argued that religiously affiliated organizations deserve government support because they provide public goods. ${ }^{66}$ Because it is based on the decisions of individuals, a tax subsidy allows the government to provide these types of public benefits while still ensuring individual religious freedom, including the freedom to contribute to organizations adverse to religion. ${ }^{67}$

\section{Efficiency}

A third reason justifying a tax subsidy is that it is efficient with respect to the amount of government cost required to fund charitable organizations. Empirical studies seem to indicate that the institution of a charitable contribution deduction induces an increase in the dollar amount of contributions to charity that is greater than the decrease in the dollar amount of tax revenues resulting from the deduction. In other words, most empirical studies indicate that the price elasticity ${ }^{68}$ of charitable giving is

65 LAURENCe H. Tribe, American Constitutional LAW 1204 (2d ed. 1988).

66 Religion is generally seen as providing a beneficial community conscience, thereby enhancing the ability of individuals to peacefully coexist. See EDITH L. FISCH et AL., CharTIES AND CharTTABLE Foundations $246 \mathrm{nn} \cdot 10-13$ (enumerating the benefits of religion to society). Religious organizations also provide needed community services. See, e.g., Walz v. Tax Comm'n, 397 U.S. 664, 674 (1970) ("[Churches provide] social welfare services or 'good works,' . . . family counselling, aid to the elderly and the infirm, and to children."); $i d$. at 708 ("Churches perform some functions that a State would ... perform. I refer to nonsectarian social welfare operations such as the care of orphaned children and the destitute and people who are sick."); Gergen, supra note 43, at 1435 n.144 ("[O]ver half the [nation's religious] congregations provide some form of social service (e.g. day care, counseling, food or shelter)...." ).

${ }^{67}$ For instance, an individual can currently receive a tax deduction for contributions to either the American Atheists, Inc. or Atheists United. See 1 INTERNAL REVENUE SERV., supra note 5, at 51, 117.

68 The price elasticity of demand is defined as the absolute value of a "percentage change in the quantity demanded divided by the percentage change in price." RUFFIN \& GREGORY, supra note 41 , at G-9. It is the increase in consumption resulting from 
greater than one. ${ }^{69}$ Thus, the cost to the government of indirect support of charitable organizations is less expensive than direct support. ${ }^{70}$

Consider the following example: a taxpayer absent government support $^{71}$ is willing to donate $\$ 1000$ to charitable organizations. The government wants to support those charitable organizations in some manner, either directly or indirectly, and is willing to spend $\$ 300$. Under a system of direct support, the cost to the government is simply the amount of its cash outlay to the organizations- $\$ 300$. The charitable organization will receive $\$ 1300$ : $\$ 1000$ from the taxpayer and $\$ 300$ directly from the government.

If instead the government chooses to support the charitable organizations indirectly, through a tax credit of $20 \%$ for example, then its cost equals the resulting decrease in tax revenues. Under this indirect system, the taxpayer is induced to donate more to charity since the government is subsidizing a portion of the cost, in effect lowering the price of donating to charity. The resulting increase in the amount of her giving, however, will be larger than the tax subsidy she receives from the government, if we assume that the price elasticity is greater than one. If the price elasticity of charitable giving is one, the taxpayer increases her pre-tax giving to $\$ 1250 .^{72}$ Since the price elasticity is greater than one, ${ }^{73}$ however,

a decrease in price. Consider, for example, a $20 \%$ decrease in the price of movies. If the decrease in the price induces you to attend $20 \%$ more movies, then your price elasticity for movies is 1 . If you instead choose to attend $30 \%$ more movies, then your price elasticity is 1.5 , an amount greater than 1 .

In the case of charitable giving, the "price" is the net cost of the donation after tax treatment. If this amount is reduced $20 \%$ through the allowance of a credit or a deduction, and the price elasticity is greater than 1 , we would expect the amount of charitable giving to increase by an amount greater than $20 \%$.

${ }^{69}$ See Feldstein, supra note 11 , at 122 (determining that the deduction encourages donors to give more than the amount of their tax savings); see also POSNER, supra note 41 , at 469 ("The charitable deduction [is] . . more efficient than direct government charitable giving in inducing charitable expenditures. If as some empirical studies have found the price elasticity of charitable giving is greater than one . . . then the charitable deduction costs the Treasury less in lost revenue than charities gain in contributions."); Wiedenbeck, supra note 23, at 95 \& n.41 ("[D]eductibility increases gifts to charity by more than it decreases tax collections.").

${ }^{70}$ In addition, as part of the private sector, charitable organizations can perhaps provide public services more efficiently than the government. Any gains from the more efficient provision of services by private charitable organizations is in addition to the efficiency advantages of the tax expenditure for charitable giving outlined in this section.

${ }^{71}$ A tax deduction, tax credit, or matching grant are all forms of government support.

72 One thousand two hundred fifty dollars is the amount at which the net cost of 
the taxpayer will increase her giving to an amount greater than $\$ 1250$, perhaps $\$ 1500 .^{74}$ Thus, under a system of indirect support the charitable organizations will receive $\$ 1500$, an increase of $\$ 200$ over the direct system of support, while the cost to the government will remain at $\$ 300$ ( $\$ 1500$ multiplied by the $20 \%$ credit). The credit, which reduces the cost of donating to charity, induces the taxpayer to make a net donation of $\$ 1200$ ( $\$ 1500$ donation less the $\$ 300$ credit) $-\$ 200$ more than she otherwise would give. Multiplied by hundreds of thousands of taxpayers, the increase in aggregate charitable contributions becomes quite significant.

\section{The CuRrent Income TaX TreatMent of INDIVIduAL CONTRIBUTIONS TO CHARITABLE ORgaNizATIONS}

\section{A. An Example}

Consider a $\$ 100$ donation by three different taxpayers under the current system. Taxpayer $I$ is a single taxpayer who works part-time at an urban convenience store. He had an $\mathrm{AGI}^{75}$ of $\$ 5500$ in 1992. Under 1992's tax code, he had zero taxable income. ${ }^{76} \mathrm{He}$ also donated $\$ 100$ to his church in 1992 , roughly two dollars a week. He had to bear the full cost of his donation and received no govern-

her donation remains at $\$ 1000$. A $\$ 1250$ contribution multiplied by a $20 \%$ tax credit equals a $\$ 250$ reduction in tax liability. One thousand two hundred fifty dollars less the $\$ 250$ reduction in her tax liability resulting from the credit equals her $\$ 1000$ net cost of donation.

${ }^{73}$ For an explanation of price elasticity, see supra note 68.

${ }^{74}$ For this illustration, a price elasticity of 2.5 has been utilized: a $50 \%$ increase in giving from $\$ 1000$ to $\$ 1500$ over the $20 \%$ reduction in price ( $50 \%$ divided by $20 \%$ equals 2.5). The remainder of this Comment uses a price elasticity of approximately 1.33-a more realistic assumption. See Wiedenbeck, supra note 23, at $95 \mathrm{n} .41$ (citing numerous studies in this range). Note that the indirect outlay still proves more efficient even with a smaller price elasticity of 1.5 . In this case, the taxpayer increases her giving by $30 \%$ to $\$ 1300$ (30\% increase in giving divided by a $20 \%$ decrease in price equals a price elasticity of 1.5 ). The charitable organization receives the same $\$ 1300$ it receives under the direct outlay system, but the cost to the government is only $\$ 260$ ( $\$ 1300$ contribution multiplied by a $20 \%$ tax credit equals a $\$ 260$ reduction in tax revenue), rather than $\$ 300$. It should be noted as well that the elasticity calculations in this Comment do not employ, for simplicity sake, the midpoints formula or some other mechanism to avoid the distortion associated with percentage changes in opposite directions. See RUFFIN \& GREGORY, supra note 41, at 95 (describing the midpoints formula).

${ }^{75}$ For a definition of AGI, see supra note 12 .

${ }^{76} \mathrm{His} 1992 \mathrm{AGI}$ is less than $\$ 5900$-the sum of his standard deduction of $\$ 3600$ plus his $\$ 2300$ personal exemption. See supra note 12 , for the definitions of standard deduction and personal exemption. 
ment reimbursement because a person with no tax liability is not eligible for any tax deductions.

Taxpayer II is single and is a nurse's aide in an urban hospital. She had an AGI of $\$ 20,000$, and did not itemize. Her taxable income was $\$ 14,100 .^{77}$ She donated $\$ 100$ to the homeless shelter she passes on her way to work in the mornings. Like Taxpayer I, she had to bear the full cost of her donation and received no government subsidy by way of a tax deduction. In her case, this occurred because she did not itemize her deductions, rather than as a result of her having no tax liability.

Taxpayer III is a single taxpayer who is a machinist in a factory. He had AGI of $\$ 32,000$ in 1992, taxable income of roughly $\$ 21,000,{ }^{78}$ and a marginal tax rate of $15 \%{ }^{79}$ His donation of $\$ 100$ went to the Salvation Army, which years earlier had helped him overcome his problem with alcohol abuse, enabling him to get back his job at the factory. This donation entitled him to increase his itemized deductions by $\$ 100$, decreasing his taxable income by $\$ 100$ and reducing his tax liability by $\$ 15$. The available subsidy, however, induced him to increase the amount of his donation to $\$ 141 .^{80}$ The government then subsidized his contribution through a reduction in his tax liability of $\$ 21.81$ Thus, Taxpayer III not only received a government subsidy for his charitable contribution, unlike Taxpayers I and II, but the government also induced a $\$ 41$ increase in the funding of his chosen charity, the Salvation Army. This increase cost the government only $\$ 21 .^{82}$

Taxpayer IV is a single taxpayer who practices environmental law as an associate in a large urban law firm. She had an AGI of $\$ 100,000$. She had taxable income of approximately $\$ 80,000^{83}$ and

${ }^{77}$ Her taxable income equals her $\$ 20,000$ AGI minus $\$ 5900$ (her standard deduction of $\$ 3600$ and her $\$ 2300$ personal exemption).

${ }^{78}$ This figure is based on his income of $\$ 32,000$ minus the $\$ 2300$ personal exemption and approximately $\$ 8700$ in itemized deductions, a reasonable estimate for deductions of a taxpayer at this income level. See CoMmERCE ClEARING House, 1993 U.S. MASTER TAX GUIDE 76 (76th ed. 1992) [hereinafter MASTER TAX GUIDE] (providing estimates drawn from IRS statistics of itemized deductions for taxpayers with different AGIs).

${ }^{79}$ See I.R.C. § 1(c), (f) (1988 \& Supp. III 1991).

${ }^{80}$ With a price elasticity of 1.33 , a $15 \%$ deduction will induce him to raise the amount of his giving by $20 \%$ to $\$ 120$ from $\$ 100$ (20\% increase in contribution divided by a $15 \%$ decrease in the cost of the contribution equals a price elasticity of 1.33). liability.

81 A donation of $\$ 141$ multiplied by a $15 \%$ deduction equals a $\$ 21$ decrease in tax

${ }^{82}$ Recall the efficiency of the deduction discussed supra part II.C.3.

83 An AGI of $\$ 100,000$ minus a $\$ 2300$ personal exemption and $\$ 17,670$ in 
donated $\$ 100$ to the local public television station, which broadcasts shows on the environment. This donation entitled her to reduce her tax liability by $\$ 31$ because she was in the $31 \%$ marginal tax bracket. ${ }^{84}$ Because she knew she would receive this subsidy, she raised the amount of her donation to $\$ 206,{ }^{85}$ obtaining a deduction of $\$ 64 .^{86}$ In this case, the government increased the funding of the local public television station by $\$ 106$ while incurring a cost of $\$ 64$. It subsidized the donation of Taxpayer IV, a high-income taxpayer, by $31 \%, 87$ in contrast to $15 \%$ for Taxpayer III, and $0 \%$ for Taxpayers I and II. Adding up the results in each example shows that the total cost to the government was $\$ 85$, which provided $\$ 147$ in subsidies to the charitable organizations favored by Taxpayers III ( $\$ 41$ to the Salvation Army) and IV ( $\$ 106$ to the public television station). No government money was provided to the church or the homeless shelter favored by lower-income Taxpayers I and II. The total aggregate level of charitable giving was $\$ 547 .^{88}$

estimated itemized deductions equals approximately $\$ 80,000$. See MASTER TAX GUIDE, supra note 78, at 76 (estimating that the average itemized deduction for a taxpayer with AGI of $\$ 100,000)$.

${ }_{84}$ See I.R.C. § 1(c), (f) (1988 \& Supp. III 1991).

${ }^{85} \mathrm{~A}$ price elasticity of 1.33 and a $31 \%$ deduction will induce her to raise the net amount of her donation $42 \%$ to $\$ 142$ from $\$ 100$ ( $42 \%$ increase in contribution divided by a $31 \%$ decrease in the cost of the contribution equals a price elasticity of approximately 1.33 ). This assumes a constant price elasticity across income levels. For a discussion of this assumption, see infra note 130 and accompanying text.

${ }^{86}$ A $\$ 206$ contribution multiplied by a $31 \%$ marginal tax rate equals a $\$ 64$ reduction in tax liability and a net contribution of $\$ 142$ (a $\$ 206$ contribution minus $\$ 64$ of tax savings).

${ }^{87}$ The phase out of itemized deductions for taxpayers with AGI in excess of $\$ 105,250$ in 1992 can lower the marginal benefit of a deduction for a charitable contribution to potentially as little as $6 \%(20 \%$ of $31 \%)$ for high-income taxpayers affected by the phase out. See I.R.C. $\$ 68$ (Supp. III 1991) (decreasing the amount of itemized deductions by the smaller of $3 \%$ of the excess AGI over $\$ 105,250$ or $80 \%$ of total itemized deductions). In a typical case, however, the marginal benefit of an additional donation for taxpayers subject to the phase out remains at $31 \%$. For example, consider the marginal benefit of an additional $\$ 1000$ charitable contribution by a hypothetical taxpayer with AGI of $\$ 250,000$ and itemized deductions of $\$ 48,000$. See MASTER TAX GUIDE, supra note 78, at 76 (estimating that the average itemized deduction for a taxpayer with AGI of $\$ 250,000$ ). Before the $\$ 1000$ contribution, $\S 68$ calls for the amount of itemized deductions to be reduced by $\$ 4342$-the lesser of $\$ 38,400$ ( $80 \%$ of $\$ 48,000$ ) or $\$ 4342$ ( $\$ 250,000$ minus $\$ 105,250$ multiplied by $3 \%$ ). After the $\$ 1000$ contribution deduction, the reduction of itemized deductions resulting from $\S 68$ remains at $\$ 4342-$ the lesser of $\$ 39,200$ ( $80 \%$ of $\$ 49,000$ ) or $\$ 4342$ ( $\$ 250,000$ minus $\$ 105,250$ multiplied by $3 \%$ ). Thus, the marginal benefit of a charitable deduction for this hypothetical taxpayer would still be $31 \%$, since the $\$ 1000$ contribution deduction would increase her itemized deductions by a full $\$ 1000$, reducing her tax liability by $\$ 310$.

${ }^{88}$ The sum of the $\$ 100$ donated by Taxpayers I and II, $\$ 141$ by Taxpayer III, and 


\section{B. A Plutocracy-A Critique of the Current System}

As previously mentioned, one benefit of an indirect subsidy is that it acts as a mechanism for the pluralistic allocation of budgetary priorities. ${ }^{89}$ Under the current system, however, this "pluralism" represents only the budgetary preferences of those with enough income to enjoy the subsidy. Although the system can still be called a form of self-government allowing individuals to say "what needs should be met, what objectives pursued, [and] what values served, $" 90$ it is an extremely inequitable form of self-government because it allocates the right to self-govern on the basis of income. Those with low income have little or no voice in allocation decisions and those with the highest income have the greatest input.

Thus, the current system fails to realize the potential for cultural pluralism inherent in the provision of public goods through a tax subsidy, and instead creates a system far worse than the political majoritarian decisionmaking of direct government expenditures. Rather than allocating budgetary outlays on the basis of the individual decisions of each citizen, a possibility if the tax benefits were available to all, it allocates the funding decision only to a very small portion of society, those with the highest income. This allocation of decisionmaking is inequitable. If individuals are to have the power to decide how public money is spent, then that power should be allocated without regard to an individual's income.

The power conferred upon high-income Americans by their ability to allocate public funds through tax deductible charitable contributions $^{91}$ is most aptly described in the context of the private foundation:

[W]e have to acknowledge the fact that private economic power is being deployed, often dynastically, through the device of the charitable foundation and the power it gives the founder and the founder's family to select the objects of their charitable bounty and to manage the charitable assets. ${ }^{92}$

$\$ 206$ by Taxpayer IV.

${ }^{89}$ See supra part II.C.1

90 GIVING IN AMERICA, supra note 57, at 123.

91 See Clotfelter, supra note 26, at 287 (examining the argument that the measurement of "the distributional impact of the charitable deduction should go beyond conventionally measured economic benefits to include the distribution of economic power" because the mechanism "concentrat[es] power at upper income levels").

${ }^{92}$ Id. at 287-88 (quoting John G. Simon, Charity and Dynasty Under the Federal Tax System, 5 PROB. LAW. 1, 5, 17, 27 (1978)). 
The power vested in high-income Americans by the current tax deduction also creates an opportunity to enjoy reciprocity for one's philanthropy. ${ }^{93}$ One view of charity is that it is support offered under the "consideration that help may be returned" in some less direct form. ${ }^{94}$ Under this view, philanthropy is granted not just for disinterested altruistic reasons, ${ }^{95}$ but for the ability to gain a return benefit of some type. If this is true, then taxpayers contribute to those charitable organizations which return benefits to them. Studies substantiate this view, finding that the type of charitable organizations supported varies by income level, with high-income taxpayers providing their government-subsidized support primarily to cultural institutions, and low-income taxpayers providing their unsubsidized support to religious institutions and community welfare agencies. ${ }^{96}$ Not surprisingly, studies indicate that wealthy taxpayers disproportionately benefit from services provided by the cultural charities such as museums, public television, and symphonies to which they allocate public money. ${ }^{97}$ Correspondingly, lowincome taxpayers donate to religious institutions and social-welfare organizations because they view those organizations as more likely to respond to their needs:

[M]utual-aid associations and churches, both characterized by aid or assistance among members, have high components of reciprocal giving. According to this view, philanthropy and everyday helping

${ }^{93}$ The law properly limits one's ability to enjoy a direct benefit in return for a contribution. See Rev. Rul, 78-232, 1978-1 C.B. 69 (stating that a deduction will be disallowed if the donor receives a benefit in exchange for the contribution). The reciprocity referred to here involves the much more indirect practice of taxpayers funding those organizations whose services they enjoy. Taxpayers who fund public television because they enjoy watching public television, or fund the symphony because they enjoy classical music are such examples.

${ }^{94}$ ClOTFELTER, supra note 26 , at 37.

${ }^{95}$ But see $i d$. at 35 (describing charitable behavior as based "on sympathetic feelings for others, social norms, or individual feelings of commitment" as well).

${ }^{96}$ See id. at 283; Martin Feldstein, The Income Tax and Charitable Contributions: Part II-The Impact on Religious, Educational and Other Organizations, 28 NAT'L TAX J. 209, 224 (1975); Wiedenbeck, supra note 23, at 101.

97 See Ronald E. Frank \& MARshall G. GreEnberg, The Public's UsE of TELEVISION 175 (1980) (finding that the viewers of public television tend to be those individuals with high incomes); Gergen, supra note 43, at $1446 \& \mathrm{n} .186$ (finding that public television viewers tend to be high-income taxpayers and also asserting that the income distinction is even more pronounced in the case of other cultural charities). This Comment takes no issue with the merits of the public funding of cultural organizations. The decision to fund such organizations, however, should be made through a process which equally considers the views and perspectives of each citizen, regardless of income. 
behavior are part of an informal mutual insurance pact .... [P]eople act charitably for the same reason they buy insurance. [T] his kind of giving brings the benefit of potential return aid $\ldots .98$

Lower-income American's support of their local religious congregations and social-welfare organizations, such as the Salvation Army, represents a form of enlightened self-interest, supporting those organizations which are most likely to offer a helping hand during difficult times, enjoying, like their higher-income counterparts, reciprocal benefits for their charitable giving. The ability to enjoy some reciprocal services for one's charity is an inevitable and acceptable aspect of private philanthropy. Unfortunately, the current deduction subsidizes only the reciprocal benefits of highincome Americans.

\section{Alternatives to THE CurRent System}

\section{A. A Matching Grant}

One possible way to confront the inequitable allocation of power is to replace the current system with a system of matching grants. Under a matching-grant system, "[e]ach donor's gift would be matched by a predetermined amount from the government, the federal share to be transmitted directly to the charitable institution of the donor's choice. ${ }^{n 99}$ For instance, each individual contribution of $\$ 100$ to a designated charity would allocate a federal matching grant directly to that charity in the amount of $20 \%$ or $\$ 20 .{ }^{100}$ Like a credit, such a system would have the benefit of eliminating the inequitable distribution of the subsidy because it would be in no way tied to income levels.

On the other hand, a matching grant would create other problems not associated with a credit. It has the potential to eliminate or deteriorate the benefits of cultural pluralism, raise constitutional issues involving subsidies to religiously affiliated

98 ClOTFELTER, supra note 26, at 37-38.

99 Paul R. McDaniel, Federal Matching Grants for Charitable Contributions: A Substitute for the Income Tax Deduction, 27 TAX L. REV. 377, 378 (1972).

${ }^{100}$ The percentage needed to maintain the current level of total giving under a matching grant system perhaps needs to be higher than that of a credit, given the potential loss of the efficiency provided by a tax expenditure. See supra part II.C.3; infra part IV.A.3. 
institutions, and cause inefficiencies associated with an indirect subsidy.

\section{Cultural Pluralism}

One concern about a matching grant program is the possible effect on the benefits of the pluralistic nature of the subsidy. The fear is that the process of deciding which charitable organizations qualify for deductible contributions might become overly politicized. The IRS, which now makes these decisions, has proven quite evenhanded and effective in its administration of the task. ${ }^{101}$ While advocates envision a system administered by the IRS (with individuals listing their charitable donations on a separate schedule with their tax return and the Treasury in turn issuing checks to the designated organizations), they acknowledge that "obviously Congress may want to look more closely at [which organizations qualify for matching grants]."102

A system where government directly funds the organization, as opposed to inducing the individual to do so, would likely be more susceptible to political intervention and opportunism than the current tax deduction. Subsidizing charitable organizations through a tax expenditure is more protective of the privacy of individual donors and their choices of to whom to donate:

When a donor takes a tax deduction for a charitable contribution his privacy is an inextricable part of the more generally protected privacy that is accorded to federal income tax returns. Thus, an attempt to breach it-for example, on the theory that deductions are equivalent to expenditures and that the public is entitled to know who is controlling the destiny of these hypothetical public funds-would be seen as a threat to the privacy of everyone's tax return .... ${ }^{103}$

101 See Wiedenbeck, supra note 23, at $99 \&$ n.49 (stating that despite numerous proposals the Commission on Private Philanthropy and Public Needs "was not persuaded that a viable alternate to the Internal Revenue Service exists and was, in fact, satisfied that, ... the Service has demonstrated its capacity for independent, impartial oversight of tax-exempt organizations including determination of exempt status"); see also Boris I. Bittker, Charitable Contributions: Tax Deductions or Matching Grants?, 28 TAX L. REV. 37, 45 (1972) ("TT]he definition of exempt organizations by section 501(c)(3) of the Code and the administration of this definition by the [IRS has] been relatively free of bias.")

102 McDaniel, supra note 99 , at 399.

103 Bittker, supra note 101 , at 45. 
A system of matching grants, by contrast, "would not be protected by a similar umbrella; and might well be swept away by a revival of McCarthyism, aided perhaps by a philosophic claim (already implicit in some proposal to substitute grants for deductions) that secrecy is incompatible with democratic values. ${ }^{\text {104 }}$ The administration of a matching-grant system would allow for "the intrusion of official concepts of right and wrong ... ${ }^{105}$ It is likely that a system of matching grants would be administered with "administrative and congressional investigations, loyalty oaths, informal or implicit warnings against heterodoxy and the other trapping of government support that the tax deduction has, so far, been able to escape." 106 For a current example, recall again the politicization of the public funding of the National Endowment for the Arts and Senator Helms's critique of the artistic choices of some Americans: "the issue really is ... indecency and rottenness, homosexuality, sodomy, bestiality. $" 107$

\section{Constitutionality}

A matching-grant system which provides matching funds to religious organizations appears to violate the restraints of the Establishment Clause, thus eliminating the benefits of the current subsidy to religiously affiliated charitable organizations. ${ }^{108}$ Reexamine the distinction made by the court in Walz v. Tax Commis$\operatorname{sion}^{109}$ which contrasted a permissible tax expenditure and a direct-money subsidy: "Obviously a direct money subsidy would be a relationship pregnant with involvement and, as with most governmental grant programs, could encompass sustained and detailed administrative relationships for enforcement of statutory or administrative standards, but that is not this case. ${ }^{\text {110 }}$ Proponents of the matching grant acknowledge the Establishment Clause problems raised by the Court's distinction in Walz between a direct

104 Id.

105 Id.

106 Id. at 46.

${ }^{107}$ See Hartigan, supra note 55 (quoting Sen. Helms after the Senate's rejection of his attempt to place content restrictions on National Endowment for the Arts grants).

${ }^{108}$ See supra part II.C.2; see also Bittker, supra note 101, at $41-42$ (arguing against a system of matching grants because it would be forced to exclude religious organizations under the Establishment Clause).

${ }^{109} 397$ U.S. 664 (1970); see supra notes 59-60 and accompanying text.

${ }^{110} \mathrm{Id}$. at 675 . 
money grant and a tax expenditure, ${ }^{111}$ however they criticize the distinction, pointing to the widely accepted theory that "tax allowances are the functional equivalent of direct grants of public funds." 112 They argue therefore that because the two are "functional[ly] equivalent," the Court should either "nullify[] tax allowances to churches or validat[e] direct grants to them." ${ }^{113}$

While a tax expenditure may provide monetary support to religious institutions equivalent to a direct matching grant, it is unclear how this addresses the concerns of the Court's Establishment Clause analysis which focuses on the level of government involvement. The Court's distinction is likely not the result of a lack of "economic sophistication," 114 but instead a recognition of the increased level of government involvement inherent in a system that requires direct grants. If, as Bittker argues, a direct matching system is more susceptible to political intervention and opportunism, ${ }^{115}$ and allows for "the intrusion of official concepts of right and wrong," 116 then the Court is justified in distinguishing between a tax expenditure and a direct grant. The current tax expenditure has been able to protect against "the relevant government decisionmaker . . . abandoning neutrality and acting with the intent of promoting a particular point of view in religious matters." 117 It is unclear how a direct matching grant system could ensure the same protection from government coercion and withstand an Establishment Clause challenge, given the likely increase of government involvement in a system of matching grants.

\section{Efficiency}

If, as empirical data seem to indicate, the price elasticity of charitable giving is greater than one, then a tax expenditure is a desirable form of support because it induces individuals to increase their contributions by an amount in excess of the revenue cost to the government. ${ }^{118}$ However, it is unclear whether a system of matching grants would result in the same efficiency.119 If a

111 See McDaniel, supra note 99, at 409-10 \& n.67.

112 Bittker, supra note 101, at 40-41; see also McDaniel, supra note 99, at 411 (arguing that the Court's distinction "will just not stand up to analysis").

113 Bittker, supra note 101, at 41 .

$114 \mathrm{McDaniel}$, supra note 99, at 410 n.67.

115 See supra notes $104-06$ and accompanying text.

116 Bittker, supra note 101, at 45.

117 Corporation of the Presiding Bishop v. Amos, 483 U.S. 327, 335 (1987).

118 See supra part II.C.3.

119 See Edward Yorio, Equity, Efficiency, and the Tax Reform Act of 1986, 55 
system of matching grants did not result in individuals increasing their donations because of the subsidy, a system of matching grants could result in the government incurring the same revenue cost while decreasing the funding of charitable organizations.

\section{B. A Deduction for Nonitemizers}

On January 5, 1993, House Ways and Means Committee member Philip M. Crane, a Republican from Illinois, introduced House Bill 152, which proposes to allow a deduction for the charitable contributions of nonitemizers. ${ }^{120}$ The proposal permits a deduction for the contributions of the seventy-eight million taxpayers who currently receive no subsidy for their charitable giving, ${ }^{121}$ going a long way toward reducing the current inequitable distribution of power in favor of higher-income taxpayers. In our example, the only taxpayer affected by the change proposed in the Crane bill would be Taxpayer II (the nurse's aide who donated $\$ 100$ to the homeless shelter). She will now be entitled to treatment identical to Taxpayer III. She will be able to deduct her contribution, and will be induced to donate $\$ 141$ to the shelter, reducing her taxes by $\$ 21 .^{122}$ The government will incur a revenue loss of $\$ 21$, and fund the homeless shelter by $\$ 41$. Taxpayer I, however, (the convenience store worker donating $\$ 100$ to his church) will still receive no subsidy for his donation and will continue to donate $\$ 100$ since he has no taxable income. A deduction, even one available to nonitemizers, will not benefit him. Likewise, the allowance of a deduction for nonitemizers will not change the treatment of Taxpayers III and IV, both of whom were already entitled to the deduction by virtue of being itemizers. So in our example, the effect of the proposed change in the law would be to increase the cost to the government by $\$ 21$, while correspondingly increasing the funding of the homeless shelter by $\$ 41$.

FORDHAM L. REV. 395, 423 (1987) ("If the deduction for charitable contributions were repealed and a matching-grant program were enacted in its stead, . . . the government incurs a cost without an offsetting benefit in the form of increased charitable giving.").

${ }^{120}$ See H.R. 152, 103d Cong., 1st Sess. (1993) (proposing "to restore and make permanent the deduction for charitable contributions by nonitemizers").

121 See supra text accompanying note 18 (explaining that 78 million taxpayers file returns but do not itemize deductions).

122 The $\$ 21$ reduction in tax liability is computed by multiplying her $\$ 141$ contribution by the $15 \%$ deduction. 
The proposed change, while an improvement on the current deduction, is inferior to a credit for three reasons. First, it keeps in place the current disproportionate subsidy of high-income taxpayers' contributions created by the progressive rate structure. The Taxpayer IVs of the nation still receive a $31 \%$ subsidy, while Taxpayers II and III continue to receive only a $15 \%$ subsidy. The overwhelming majority of the seventy-eight million taxpayers to whom this proposal grants a deduction are in the $15 \%$ marginal tax bracket, ${ }^{123}$ while the higher-income taxpayers at the $31 \%$ marginal rate continue to receive a higher subsidy for their charitable giving.

Second, the deduction for nonitemizers allocates no subsidy to the philanthropy of the over twenty-two million zero bracket taxpayers $^{124}$ like Taxpayer I (the convenience store employee) who do not earn enough to take advantage of the deduction. A deduction is of no value to a taxpayer who without the deduction already has zero taxable income. A refundable tax credit provides these individuals with an equal subsidy. ${ }^{125}$

Third, unlike this Comment's revenue-neutral credit, the Crane proposal results in a net loss of federal tax revenue, since it extends the deduction to nonitemizers without a corresponding reduction in the subsidy provided to itemizers. ${ }^{126}$ Using the numbers from our example, this proposal costs the government $\$ 21$, but there is no corresponding increase in revenue (although the homeless shelter's funding would increase by $\$ 41$ because of the efficiency of the indirect subsidy).

${ }^{123}$ Over $88 \%$ of nonitemizing households have, on average, taxable income of less than $\$ 22,000$. See INTERNAL REVENUE SERV., supra note 13 , at 21,35 (placing such taxpayers well within the $15 \%$ marginal bracket); see also I.R.C. $\$ 1(c)$, (f) (1988 \& Supp. III 1991) (delineating that the $15 \%$ bracket ends at roughly $\$ 22,000$ for single taxpayers and roughly $\$ 36,000$ for married taxpayers filing jointly).

124 See STATISTICAL ABSTRACT, supra note 17, at 452.

125 See supra note 22 and accompanying text.

126 See Wartzman, supra note 25, at A1 (describing a deduction for nonitemizers as "costly"). The Crane bill provides a subsidy to the 78 million taxpayers who do not itemize, while leaving in place the amount of the subsidy granted to high-income taxpayers. A $20 \%$ tax credit reduces the amount of the subsidy for high-income taxpayers in the $31 \%$ and $28 \%$ marginal tax brackets to $20 \%$, while increasing the subsidy of those individuals facing a $0 \%$ and $15 \%$ marginal tax rate. The decrease in the subsidy for higher-income taxpayers increases revenue. The Crane bill provides no offsetting revenue increase. This Comment argues that the revenue increase in lowering the subsidy for higher-income taxpayers will roughly equal the revenue outlay for increasing the subsidy for lower-income taxpayers, making the proposal revenue neutral at a particular percentage amount. See infra part IV.C.1. 


\section{A Refundable Credit}

\section{The Proposal}

This Comment proposes that the current system utilizing deductions should be replaced with a refundable tax credit, which provides an equal subsidy across income levels, similar to the system of matching grants. The credit should be equal to the amount of qualified charitable contributions times a revenue-neutral percentage level. For the sake of example, this Comment assumes the percentage to be $20 \%{ }^{127}$ In our example, this means that the treatment of each taxpayer's $\$ 100$ donation is identical. Each is entitled to a $20 \%$ tax credit for the amount of their contribution. The decrease in the cost of giving causes each taxpayer in our example to increase his or her donation to $\$ 159,,^{128}$ and entitles each to a tax credit of $\$ 32 .{ }^{129}$

Noted empirical studies which have examined this issue indicate that a shift to a revenue-neutral credit would not create a change in the total amount of charitable giving, since the price elasticity of giving appears to be constant across income levels. ${ }^{130}$ If price elasticity is constant across income levels and the level of the credit is chosen to keep the revenue cost at the same amount as the

127 Twenty percent is a rough estimate of the level of credit necessary to maintain the revenue cost at $\$ 17$ billion. See supra note 2 . The preceding studies cited examine the effect of a 25\% credit, but such studies were conducted prior to the 1986 Act's reduction in rates. See infra note 130 . It seems likely that a lower credit would currently be necessary to maintain revenue neutrality. The government should and would study the revenue impact in determining the level of credit necessary to maintain the current revenue cost of the tax expenditure.

${ }_{128}$ This represents a $27 \%$ increase in the net cost of their donations from $\$ 100$ to $\$ 127$ ( $\$ 159$ donation minus the $\$ 32$ credit), since each taxpayer has a price elasticity of roughly 1.35 (27\% increase in charitable contribution divided by a $20 \%$ reduction in the price of the contribution).

129 The $\$ 32$ refund is computed by multiplying the $\$ 159$ charitable contribution by the $20 \%$ tax credit.

${ }^{130}$ See Feldstein, supra note 96, at 209-10 ("[T]he econometric evidence indicates that the price elasticity of giving ... does not differ significantly among income groups ... . "); Wiedenbeck, supra note 23, at $101 \mathrm{n} .54$ ("The data reveal that price elasticity ... does not vary significantly through a wide range of incomes."). Nevertheless, these studies are by no means conclusive, and substantial disagreement does exist over the price elasticity for taxpayers at different income levels. See e.g., CLOTFELTER, supra note 26 , at 66-71 (ultimately concluding that " $t$ ] he evidence summarized here provides no firm conclusion regarding the important issue of variation in the price elasticity by income level"). The likelihood of a small or nonexistent difference in price elasticity seems strong enough to support changing to a credit without significant concern about a decrease in aggregate giving. 
current deduction (that is, a revenue-neutral change) then total aggregate giving will be unchanged. ${ }^{131}$ "[T]he substitution of a ... credit would yield approximately the same total aggregate giving at the same revenue cost as the current deduction, even though the credit would present the same cost of giving to all taxpayers. ${ }^{\text {"132 }}$ In our example, this means that net cost to government-the revenue loss-stays at $\$ 85$, while maintaining the total subsidy to charitable organizations at an amount of $\$ 147$, and the total aggregate giving at $\$ 547 .{ }^{138}$

Though a shift to a credit would not change the total aggregate level of charitable giving, it "would have a dramatic impact on the distribution of contributions," that is which organizations are funded, and by whom. ${ }^{134}$ Every American across all income levels would have a say in the allocation of the $\$ 17$ billion government subsidy to charitable organizations. Each American would be able to participate in this "form of self-government" by "saying with his or her dollars what needs should be met, what objectives pursued, what values served." 135 In our example, this means that the treatment of each individual is identical. ${ }^{136}$ Each would be entitled to a $20 \%$ credit for the amount of their contribution. The government would subsidize equally ${ }^{137}$ the decision of Taxpayer I to support his local

131 Because the sensitivity to the net price of giving is constant across income levels, "the total cost in terms of foregone tax revenue is essentially independent of the method used to stimulate contributions." Feldstein, supra note 96, at 210.

132 Wiedenbeck, supra note 23 , at 101 n.54.

133 Actually, following through in the example results in a revenue loss to the government of $\$ 43$ (a $\$ 32$ credit for each of the four taxpayers of $\$ 128$ less the existing $\$ 85$ revenue cost), an increase in the subsidy to charity of $\$ 236$ (a $\$ 59$ increase in each of the four taxpayer's donations), and an increase in total aggregate giving to $\$ 89$ (a $\$ 159$ donation from each of the four taxpayers of $\$ 636$ less the existing level of \$547). This revenue loss of the proposal and the increase in the amount of charitable giving results from the decision to include within the example a disproportionate amount of lower-income giving in order to demonstrate the effect of different possible changes in the law on these lower-income taxpayers. Thus, the decrease in charitable giving and corresponding tax savings for those taxpayers facing the $28 \%$ and $31 \%$ marginal tax rates is understated in the example and the increase in giving and corresponding revenue cost of lower-income taxpayers facing a zero and $15 \%$ marginal tax rate is overstated, causing our example to, in total, overstate the net revenue loss and the increase in charitable giving.

134 Wiedenbeck, supra note 23, at 101.

135 GIVING IN AMERICA, supra note 57, at 123.

136 Keep in mind the caveat of supra note 23, regarding the ability of high-income taxpayers to designate a larger subsidy through their ability to contribute larger amounts.

${ }^{137}$ The amount of the subsidy is $\$ 59$ (the $\$ 159$ donated after the credit as compared to the $\$ 100$ donated without the subsidy), at a cost to the government of 
church, the decision of Taxpayer II to fund the homeless shelter, the decision of Taxpayer III to donate to the Salvation Army, and the decision of Taxpayer IV to provide for public television.

\section{Confronting Concern}

\section{a. Compliance and Cost}

Part of the reason given for the repeal of the deduction for nonitemizers in the 1986 Act was the cost associated with taxpayers having to substantiate contributions and the IRS having to verify more numerous and smaller contributions. ${ }^{138}$ Currently, IRS regulations require that cash contributions be substantiated by one of the following: (i) a "cancelled check"; (ii) a "receipt from the donee charitable organization"; or (iii) in "the absence of [(i) or (ii)] . . o other reliable written records [produced by the taxpayer which] "show[] the name of the donee, the date of the contribution, and the amount of the contribution." ${ }^{139}$ The reliability of the records listed in (iii) is "determined by reference to facts and circumstances" such as the "contemporaneous nature" of the records and the "regularity of the taxpayer's recordkeeping procedures." 140 In all cases, however, "the burden shall be on the taxpayer to establish reliability." 141

Unquestionably, extending the subsidy for charitable contributions involves an increase in record keeping costs by taxpayers because more of them would be concerned with substantiating their deduction. ${ }^{142}$ Nevertheless, the substantiation of most charitable giving requires very little extra effort on the part of the taxpayer. As provided in the regulation, any donation made by check provides an instant record. To the extent that poorer taxpayers are more likely to donate in cash, they could as easily obtain a receipt for

\$32 (the cost of foregone tax revenue from each taxpayer is equal to the amount of the credit ( $\$ 159$ multiplied by the $20 \%$ credit equals $\$ 32)$ ).

${ }^{138}$ See Ronald A. Pearlman, Repeal of Charitable Contributions for Nonitemizers Explained, 28 TAX NOTES 1140 (1985) (arguing that the nonitemizer deduction is "administratively burdensome" because the IRS "is forced to verify numerous small contributions, and taxpayers must maintain records substantiating such contributions").

${ }_{139}$ Treas. Reg. $\$ 1.170 \mathrm{~A}-13(\mathrm{a})(1)$ (as amended in 1988).

${ }^{140} I d . \S 1.170 \mathrm{~A}-13(\mathrm{a})(2)(\mathrm{i})$.

141 Id.

142 See ClOTFELTER, supra note 26, at 284 (“[T] extension of a tax subsidy for charitable gifts to low-income households might require significant increases in record keeping by taxpayers."). 
each contribution or maintain a simple record of donations as required by the regulation.

The additional cost to the IRS of verifying the donations of lower-income taxpayers is also overstated. While the expansion of a credit to more taxpayers will potentially involve some additional cost, it is not clear that the use of standard verification methods will be unable to detect fraudulently reported contributions. ${ }^{143}$ While compliance presents the most legitimate concern with expanding the subsidy to lower-income taxpayers, the additional costs that might be incurred cannot justify denying 100 million households $^{144}$ a voice in deciding which charitable organizations should receive the $\$ 17$ billion of public funding.

\section{b. Hiding the Subsidy}

As discussed in connection with direct matching grants, part of the benefit of the current system is to shield the subsidy of charitable organizations from political manipulation by administering it through the tax system, as opposed to a system of direct matching contributions. The tax credit has also been criticized as being susceptible to political control. ${ }^{145}$ Critics of the credit claim that it would be more easily "recognized as a means of government assistance" of charitable organizations than is a deduction, exposing the choice of which various charitable organizations qualify for the subsidy to political intervention and opportunism. ${ }^{146}$ Even assuming that a credit system would more easily be recognized as a subsidy of charitable organizations (which is not

143 Currently, the "vast majority of IRS audits are triggered by the agency's computers" which analyze the "interrelationship of various items on the return," by comparing "what other people in the same income bracket have typically claimed." Rick Wartzman, Don't Wave a Red Flag at the IRS, WALl ST. J., Feb. 24, 1993, at C1 ('We look for how things play against each other,' explains Mike Killfoil, the IRS's acting assistant commissioner for examination."). In the case of a charitable contribution credit, an audit trigger for donations reported in excess of a reasonable percentage of AGI could catch many taxpayers who fraudulently reported charitable contributions.

144 The 100 million individuals represent 22 million who are zero bracket taxpayers, see STATISTICAL ABSTRACT, supra note 17, at 452, plus 78 million taxpayers who do not itemize deductions, see INTERNAL REVENUE SERV., supra note 13, at 2.

145 See Wiedenbeck, supra note 23, at 101 (citing the Commission on Philanthropy and Public Needs as rejecting the tax credit for this reason). It is likely however that the amount of the subsidy provided charitable organizations is more susceptible to adjustment, since changing the level of a credit is easier than changing the benefit provided by a deduction.

146 Wiedenbeck, supra note 23, at 101. 
entirely clear), fair, even-handed administration of the question of which organizations qualify for the credit would be maintained, because the IRS would continue to decide this question under a credit system. ${ }^{147}$ Likewise, an individual's contribution would continue to receive the "privacy that is accorded to federal income tax returns," under a credit system. ${ }^{148}$

\section{CONCLUSION}

The current tax preference granted an individual's charitable contribution is properly viewed as a mechanism to provide government support to charitable organizations. The provision of a public subsidy through the tax system efficiently provides support in a manner that ensures cultural and religious pluralism. The historical development and expansion of the standard deduction and the progressive tax structure, however, have created a system which predominantly subsidizes the charities favored by high-income taxpayers. This Comment has considered alternatives to the current inequitable plutocratic allocation of power and proposes a refundable tax credit to replace the current deduction. The tax credit will greatly reduce the inequity of the current system while maintaining revenue cost and aggregate giving at current levels.

117 Recall our discussion of the IRS's freedom from bias in its administration of this question. See supra notes 101-02 and accompanying text.

${ }^{148}$ Bittker, supra note 101 , at 45 . 